\title{
PEMANFAATAN METODE KONSEP KALIMAT DALAM KARTU DALAM KALIMAT UNTUK MENINGKATKAN KEMAMPUAN BERSIKAP KRITIS TERHADAP NILAI-NILAI KRISTIANI BAGI SISWA KELAS X IPA 1 DAN X IPA 2 DI SMA NEGERI 3 KOTA SORONG TAHUN 2017
}

\author{
Lenyanti Palin
}

\begin{abstract}
${ }^{1}$ SMA Negeri 3 Sorong JI. Jend. Sudirman No 49, Sorong, Indonesia lenipalin@gmail.com
\end{abstract}

\begin{abstract}
Penelitian ini bertujuan untuk mengetahui peningkatan kemampuan bersikap kritis terhadap nilai- nilai Kristiani bagi siswakelas X IPA 1 dan X IPA 2 diSMA Negeri 3 Kota Sorong melalui pemanfaatan metode kalimat dalam kartu. Jenis penelitian ini adalah penelitian tindakan kelas (Classroom Action Research) yang dilakukan secara kolaboratif antara peneliti dengan guru. Penelitian dilaksanakan dalam dua siklus, masing-masing siklus terdiri dari empat komponen yaitu perencanaan, tindakan, pengamatan dan refleksi. Teknik pengumpulan data yang digunakan dalam penelitian ini adalah wawancara, observasi, dokumentasi dan tes. Analisis data dilakukan dalam 3 tahap yaitu reduksi, penyajian data serta menarik kesimpulan. Hasil penelitian menunjukkan bahwa: (a) pemanfaatan metode consept sentencedapat meningkatkan partisipasi belajar siswa. Peningkatan kemampuan bersikap kritis terhadap nilai- nilai Kristiani dapat dilihat melalui aspek mendengarkan penjelasan pada siklus I sebesar $47 \%$ meningkat menjadi sebesar $51 \%$ pada siklus II. Partisipasi dalam mencatat penjelasan siklus 1 sebesar $43 \%$ meningkat menjadi sebesar $69 \%$ pada siklus II. Partisipasi dalam memperhatikan pembelajaran siklus I sebesar $49 \%$ meningkat menjadi sebesar $60 \%$ pada siklus II. Partisipasi dalam bertanya siklus I sebesar $43 \%$ meningkat menjadi sebesar $66 \%$ pada siklus II. Partisipasi dalam menjawab pertanyaan siklus I sebesar $49 \%$ meningkat menjadi sebesar $66 \%$ pada siklus II. Partisipasi dalam mengeluarkan pendapat siklus I sebesar $46 \%$ meningkat menjadi sebesar $63 \%$ pada siklus II. Partisipasi dalam menghargai pendapat teman siklus I sebesar $49 \%$ meningkat menjadi sebesar $66 \%$ pada siklus II. Partisipasi dalam menjelaskan kembali siklus I sebesar $40 \%$ meningkat menjadi sebesar $60 \%$ pada siklus II. (b) Pemanfaatan metode consept sentencedapat meningkatkan prestasi belajar siswa. Rata-rata hasil belajar siswa pada siklus I sebesar 69,64 meningkat menjadi 78,4 pada siklus II
\end{abstract}

Keywords concept sentence, kemampuan bersikap kritis terhadap nilai-nilai Kristiani, SMA Negeri 3 Kota Sorong

\section{PENDAHULUAN}

Pendidikan adalah usaha sadar dan terencana untuk mewujudkan suasana belajar dan proses pembelajaran agar peserta didik secara aktif mengembangkan potensi dirinya untuk memiliki kekuatan spiritual keagamaan, pengendalian diri, kepribadian, kecerdasan, akhlak mulia, serta keterampilan yang diperlukan dirinya dan masyarakat. Negara yang maju adalah Negara yang pendidikannya maju pula, dan demikian sebaliknya. Jadi pendidikan menopang kemajuan bangsa itu. Itulah sebabnya mutu pendidikan yang rendah menjadi keprihatinan bangsa secara keseuruhan, bukan hanya kalangan tertentu yang terlibat dalam proses pendidikan.

Dunia pendidikan sebagai ruang bagi peningkatan kapasitas anak bangsa haruslah dimulai dengan sebuah cara pandang bahwa pendidikan adalah bagian untuk mengembangkan potensi, daya pikir dan daya nalar serta pengembangan kreatifitas yang dimiliki. Pendidikan memiliki peran yang sangat penting dalam mewujudkan masyarakat yang berkualitas, terutama dalam mempersiapkan peserta didik menjadi subjek yang semakin berperan menampilkan keunggulan dirinya yang tangguh, kreatif, mandiri dan profesional pada bidangnya masing-masing. 
Proses pembelajaran memerlukan suatu strategi pembelajaran untuk mencapai tujuan pendidikan tertentu. Secara khusus dalam proses pembelajaran guru berperan sebagai pengajar, pembimbing, perantara sekolah dengan masyarakat, administrator dan lain-lain. Untuk itu wajar bila guru memahami dengan segenap aspek pribadi anak didik seperti: (1) kecerdasan dan bakat khusus, (2) prestasi sejak permulaan sekolah, (3) perkembangan jasmani dan kesehatan, (4) kecenderungan emosi dan karakternya, (5) sikap dan minat belajar, (6) cita-cita, (7) kebiasaan belajar dan bekerja, (8) hobi dan penggunaan waktu senggang, (9) hubungan sosial di sekolah dan di rumah, (10) latar belakang keluarga, (11) lingkungan tempat tinggal, dan (12) sifat-sifat khusus dan kesulitan belajar anak didik. Usaha untuk memahami anak didik ini bisa dilakukan melalui evaluasi, selain itu guru mempunyai keharusan melaporkan perkembangan hasil belajar para siswa kepada kepala sekolah, orang tua, serta Instansi yang terkait, tidak terkecuali pada SMA Negeri 3 kota Sorong terletak di tengah kota Sorong dan merupakan salah satu sekolah rujukan di provinsi Papua Barat. Oleh karena itu siswa/siswi SMAN 3 kota Sorong sebagai remaja Kristen hendaknya lebih memahami nilai nilai Kristiani

Kondisi di atas tidak sesuai dengan harapan peneliti.Saat peneliti mengajar di kelas X IPA 1 dan X IPA 2dijumpai 75\% siswa tidak memahami materi nilai-nilai Kristianil. Siswa saat kegiatan pembelajaran jika ditanya guru tidak mampu menjawab. Apalagi jika diminta bertanya. Separuh siswa tidak berani mengemukakan pendapat.

Dari permasalahan tersebut, peneliti merasa bahwa kemampuan menguasai materi bersikap kritis terhadap nilai- nilai Kristiani perlu dipahami siswa. Hal ini di karenakan nilai rata-rata kelas belum mencapai KKM yang diharapkan. Selain itu saat ditanya guru siswa tidak mampu menjawab. Saat kegiatan belajar mengajar suasana kelas sangat monoton sehingga perlu dicari strategi pembelajaran yang merangsang siswa untuk aktif, kreatif, dan menyenangkan.

Berdasarkan permasalahan yang terjadi maka penulis tertarik untuk melakukan penelitian dengan tujuan untuk mendeskripsikan peningkatan kemampuan bersikap kritis terhadap nilai- nilai Kristiani melalui metode consept sentence bagi siswa kelas X IPA 1 dan X IPA 2 di SMA Negeri 3 Kota Sorong Tahun 2017. Sejalan dengan itu tujuan khusus penelitian ini adalah:

1. Mendeskripsikan proses tindakan peningkatan kemampuan pemahaman terhadap nilai- nilai Kristiani bagi siswa kelas X IPA 1 dan X IPA 2 di SMA Negeri 3 Kota Sorong?

2. Mendeskripsikan proses tindakan peningkatan kemampuan bersikap kritis terhadap nilai- nilai Kristiani bagi siswa kelas X IPA 1 dan X IPA 2 di SMA Negeri 3 Kota Sorong?

3. Mendeskripsikan hasil tindakan peningkatan kemampuan bersikap kritis terhadap nilainilai Kristiani bagi siswa kelas X IPA 1 dan $X$ IPA 2 di SMA Negeri 3 Kota Sorong?

\section{KAJIAN LITERATUR}

\subsection{Metode Concept Sentece}

Metode consept sentence adalah metode pembelajaran dengan cara memberikan kartukartu yang berisi kata kunci untuk dibuat kalimatkalimat, yang selanjutnya disusun menjadi sebuah paragraf. Pada setiap kata kunci dibuat minimal empat kalimat.

Dalam melaksanakan metode concept sentence terdapat langkah-langkah yang perlu dilakukan (Kiranawati: 2008). Langkah-langkah dalam pembelajaran dengan metode concept sentence meliputi,

1) guru menyampaikan kompetensi yang akan dicapai,

2) guru menyajikan materi terkait dengan pembelajaran secukupnya,

3) guru membentuk kelompok yang anggotanya kurang lebih 6 orang secara heterogen,

4) guru menyajikan beberapa kata kunci sesuai dengan materi yang disajikan,

5) setiap kelompok diminta untuk membuat beberapa kalimat dengan menggunakan minimal 4 kata kunci setiap kalimat,

6) hasil diskusi kelompok didiskusikan kembali secara pleno yang dipandu oleh guru, dan 
7) siswa dibantu oleh guru memberikan kesimpulan.

Terdapat beberapa kelebihan metode pembelajaran concept sentence. Kelebihan metode concept sentence tersebut meliputi: (Kiranawati: 2008).

1) Meningkatkan semangatbelajar siswa,

2) Membantu terciptanya suasana belajar yang kondusif,

3) Memunculkan kegembiraan dalam belajar,

4) Mendorong dan mengembangkanproses berpikir kreatif,

5) Mendorong siswa untuk memandang susuatu dalampandangan yang berbeda,

6) Memunculkan kesadaran untuk berubah menjadilebih baik,

7) Memperkuat kesadaran diri.

8) Lebih memahami kata kunci darimateri pokok pelajaran

9) Siswa yang lebih pandai mengajari siswa yang kurang pandai

\subsection{Kemampuan Bersikap Kritis Terhadap} Nilai- nilai Kristiani

a. Pengetian nilai

Nilai merupakan realitas yangt abstrak , yang dapat dirasakan dalam diri kita masing-masing sebagai daya dorong atau prinsip atau pedoman dalam hidup manusia secara praktis. Nilai adalah perasaan tentang apa tentang apa yang diinginkan atau tidak diinginkan yang dapat mempengaruhi perilaku seseorang yang memiliki nilai tersebut.setiap orang memiliki tata nilai yang digunakan untuk menilai baik buruknya sesuatu dalam kehidupannya seperti hal-hal jasmani, rasa kepercayaan, keyakinan dan sebagainya. Karena itu nilai merupakan sisi yang sangat penting dan melekat erat dalam hidup manusia dalam pola piker serta pola tingkahlaku. Nilai ditanamkan pada seseorang dalam suatu proses sosialisasi dalam lingkup keluarga, masyarakat/ lingkungan ,lembaga pendidikan agama, media massa, tradisi dan kelompok-kelompok sebaya ( kaswardi, 1993:20-23). Biasanya suatu nilai erat hubungannya dengan suatu konsepm yang berakar dari dalam emosi masyarakat. Sehubungan dengan itu dengan itu nilai budaya disebut system nilai budaya yaitu suatu system yang terdiri dari konsepsi-konsepsi yang hidup dalam alam pikiran sebagian besar masyarakat tentang hal-hal yang dianggap bernilai atau berharga dalam hidup. Nilai tersebut tertanam dalam kondisi-kondisi sosio ekonomi, nilai-nilai tersebut merupakan kondisi yang tertutup.

b. Nilai-nilai Kristiani

Nilai Kristiani erat hubungannya dengan ajaran Kristen, khususnya etika Kristen. Etika Kristen merupakan tanggapan kasih Allah yang menyelamatkan manusia ( 1 Yoh. 4:19). Titik tolak iman Kristen adalah Iman kepada Tuhan yang menyatakan diri dalam Tuhan Yesus Kristus . Dalam konteks iman Kristen ukuran apa yang baik adalah segala sesuatu yang sesuai dengan kehendak Tuhan .sedangkan kehendak Tuhan itu dinyatakan dalam hukum dan perintahNya yakni dalam dasa titah dan kasih sebagai landasan yang utama. Etika Kristen inilah yang mengontrol , mengoreksi dan mengarahkan perbuatan orang orang Kristen dalam bertindak secara nyata. Dasar yang digunakan adalah Firman Tuhan seperti dalam Keluaran 20:1-17 dan yang didasarkan dalam hukum kasih yaitu Mat. 22:37-40: Mark. 12:30-31; Luk. 10:27 yaitu:

1) Mengasihi Allah dengan segenap hati, segenap jiwa, segenap akal budi, dan segenap kekuatan kita, merupakan hukum yang pertama dan merupakan ringkasan dari hukum 1-4.

2) Mengasihi sesame manusiaseperti mengasihi diri sendiri, merupakan hukum kedua danmerupakan ringkasan dari hukum 6-10. 
Nilai-nilai Kristiani khususnya tentang kasih diterangkan secara praktis dalam 1 Kor. 13: 4-8 antar lain:

1) Sabar,

2) Murah hati,

a. Tidak cemburu,

3) Tidak memegahkan diri dan tidak sombong,

4) Tidak melakukan yang tidak sopan dan tidak mencari keuntungan sendiri,

5) Tidak pemarah dan tidak menyimpan kesalahan orang lain,

6) Tidak bersukacita karena ketidak adilan tetapi karena kebenaran,

7) Menutupi segala sesuatu, percaya segala sesuatu, sabar menanggung segala sesuatu.

c. Sumber nilai Kristiani

Nilai-nilai kristiani tentunya tidak lepas dari sifat-sifat Allah. Seperti dalam Mat.5:8 nilai nilai yang harus diteladani manusia dari Yesus Kristus adalah:

1. Kebenaran, yaitu kita harus memegang kebenaran dan mengajarkannya dalam kebenaran berdasar pada Alkitab. Kebenaran ini juga terletak integritas dan kejujuran, yaitu ada keselarasan antara apa yang dikatakan dan apa dilakukan.

2. Kesalehan, disini setiap orang percaya harus hidup berfocus dan berpusat pada Allah Bapa didalam nama Tuhan Yses Kristus. Kesalehan berbicara tentang hubungan atau relasi antara kita dengan Allah dan kesederhanaan hidup

3. Kekudusan, merupakan syarat seseorang dapat melihat Allah danmasuk menhadap hadiratnya. Orang Kristen dikuduskan untuk menjadi garam dan terang dunia

4. Kesetiaan, sifat setia sangat diharapkan untuk dapat dimiliki oleh setiap orang percaya. Kesetiaan orang Kristen harus didasarkan pada kesetiaan Allah sendiri yang senantiasa menyertai kita.

5. Keutamaan, semangat untuk memberikan yang terbaik untuk Tuhan dan sesame yang diilhami oleh Allah sendiri yang telah memberikan pemberian yang terbaik yaitu AnakNya yang tunggal bagi dunia.

6. Keadilan, adil artinya sama berat, tidak berat sebelah tidak memihak tetapi berpegang pada kebenaran, atau memeberikan sesuatu kepada seseorang sesuai dengan haknya. Olehsebab itu kita harus terlibat dengan aktif dalam segala upaya menegakkan keadilan Tuhan dimanapun kita berada, karena Tuhan peduli kepada setiap orang benar yang ditindas kefasikan, kemunafikan, atau kefanatikan orang lain.

7. Kasih, merupakan ciri kehidupan umat Kristiani yang selalu dinantikan oleh orang-orang yang ada disekitar kita. Kasih yang dinyatakan dengan kesediaan untuk menerima orang lain, mengampuni yang bersalah dan menyalurkan berkat Tuhan bagi mereka yang membutuhkan. Sumber nilai Kristiani yang lain dalam Alkitab adalah dalam Galatia 5:22-23 yaitu:

- Kasih

- Sukacita

- Damai sejahtera

- Kesabaran

- Kemurahan

- Kebaikan

- Kesetiaan

- Kelemahlembutan

- Penguasaan diri

\subsection{Kerangka Berpikir}

Proses pembelajaran yang dilakukan di dalam kelas merupakan aktivitas mentransformasikan pengetahuan, sikap, dan 
keterampilan. Proses pembelajaran ini menuntut keaktifan siswa, di mana siswa adalah subjek yang banyak melakukan kegiatan, sedangkan guru sebagai fasilitator lebih banyak membimbing dan mengarahkan.

Pembelajaran pada Agama dan budi pekerti di SMA Negeri 3 Kota Sorong kurang variatif. Cara penyampaian teori masih menggunakan metode ceramah dan mencatat. Tentunya pemahaman siswa tentang kemampuan bersikap kritis terhadap nilai- nilai Kristiani masih dirasa kurang. Hal tersebut dapat mengakibatkan partisipasi siswa rendah sehingga akan mengakibatkan prestasi belajarnya menjadi rendah. Oleh karena itu diperlukan inovasi lain yang dapat menarik perhatian siswa.

Pemanfaatan metode concept sentencepada proses pembelajaran akan menarik perhatian dan rasa ingin tahu siswa. Pemanfaatanmetode concept sentencedalam pembelajaran akan memberikan kemudahan bagi siswa dalam memahami serta mengingat kembali kemampuan bersikap kritis terhadap nilai- nilai Kristiani. Dengan demikian, penggunaan metode concept sentencepada proses pembelajaran dapat mendorong siswa dalam meningkatkan prestasi belajar.

Untuk meningkatkan partisipasi aktif dan prestasi belajar siswa, maka diperlukan inovasi baru. Salah satunya adalah dengan memanfaatkan metode concept sentence.

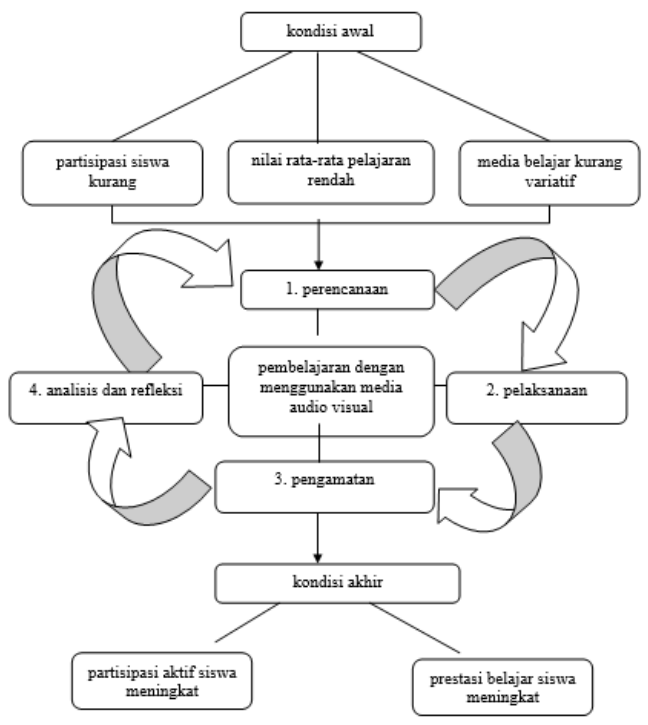

Gambar 1. Skema Kerangka Pikir Penelitian Tindakan

\subsection{Hipotesis Tindakan}

Hipotesis tindakan dari penelitian ini adalah pemanfaatan metode concept sentencedapat meningkatkan kemampuan bersikap kritis terhadap nilai- nilai Kristiani bagi siswa kelas $\mathrm{X}$ IPA 1 dan X IPA 2 di SMA Negeri 3 Kota Sorong tahun 2017.

\section{METODE PENELITIAN}

\subsection{Desain Penelitian}

Penelitian ini merupakan penelitian tindakan kelas (classroom action research), yaitu pencermatan terhadap kegiatan belajar berupa sebuah tindakan, yang sengaja dimunculkan dan terjadi dalam sebuah kelas secara bersama. Dalam pelaksanaannya peneliti dapat melakukan penelitian tindakan kelas secara mandiri ataupun kolaboratif, akan tetapi tidak boleh menghambat kegiatan utama guru dalam proses pembelajaran.

Penelitian ini dilakukan secara kolaboratif dan partisipatif. Secara partisipatif bersama-sama mitra peneliti melaksanakan penelitian ini langkah demi langkah. Selain partisipatif, peneliti dapat berkolaborasi dengan guru Standar Kompetensi kemampuan bersikap kritis terhadap nilai- nilai Kristiani dengan tujuan memperbaiki kekurangankekurangan dalam praktik pembelajaran. Dalam penelitian tindakan kelas ini, guru bertindak sebagai pelaksana tindakan sedangkan peneliti bertindak sebagai kolaborator.

Penelitian tindakan kelas ini dilakukan oleh peneliti, mencoba menemukan suatu gagasan yang kemudian diterapkan dalam upaya perbaikan pada praktik pembelajaran yang dilakukan. Dalam penelitian tindakan ini mencoba menerapkan variasi model pembelajaran yang baru yaitu pada model pembelajaran menggunakan metode concept sentenceyang diharapkan dapat memberikan perubahan ke arah perbaikan pada suatu proses pembelajaran. Dalam penelitian tindakan kelas ini terdiri atas rangkaian empat kegiatan yang dilakukan dalam siklus berulang. Empat kegiatan utama yang ada pada setiap siklus, yaitu :

1. Perencanaan (planning), yaitu persiapan yang dilakukan untuk pelaksanaan PTK. 
2. Tindakan (acting), yaitu deskripsi tindakan yang akan dilakukan, scenario kerja tindakan, perbaikan kerja yang akan dilakukan dan prosedur tindakan yang diterapkan.

3. Observasi (observing), yaitu kegiatan mengamati dampak atastindakan yang dilakukan. Kegiatan ini dapat dilakukan dengan cara pengamatan, wawancara atau cara lain yang sesuai dengan data yang dibutuhkan.

4. Refleksi (reflecting), yaitu kegiatan evaluasi tentang perubahan yang terjadi atau hasil yang diperoleh atas data yang terhimpun sebagai bentuk dampak tindakan yang telah dirancang.

Adapun siklusnya dapat digambarkan sebagai berikut :

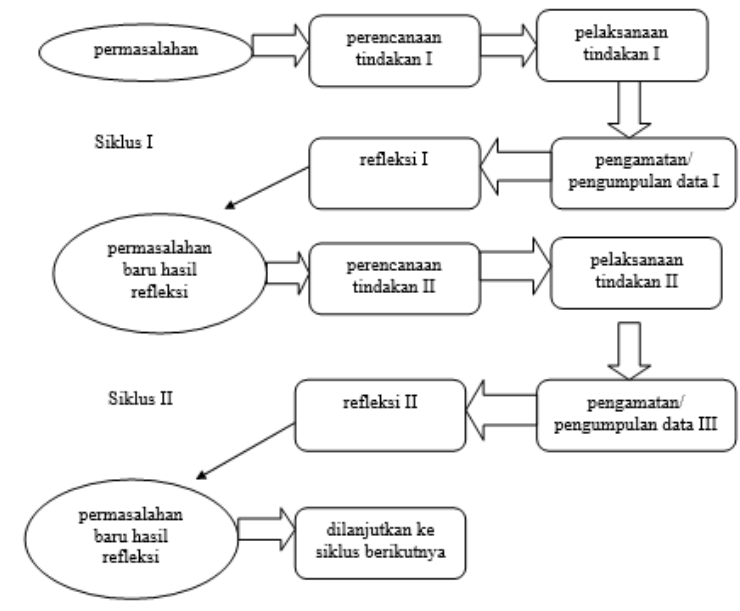

Gambar 2. Siklus Penelitian Tindakan Kelas (Suharsimi Arikunto, 2017: 74)

\subsection{Tempat dan Waktu Penelitian}

Penelitian dilaksanakan pada tanggal 2 September sampai dengan 25 September 2017 di SMA Negeri 3 Kota Sorong yang beralamat di Jl. Jend Sudirman no. 49 Kota SorongKota Sorong.

\subsection{Subjek dan Objek Penelitian}

Subjek dalam penelitian ini adalah siswa SMA Negeri 3 Kota Sorong. Sedangkan yang menjadi objek penelitian adalah kemampuan bersikap kritis terhadap nilai- nilai Kristiani dengan pemanfaatan metode concept sentence. Peneliti memilih siswa kelas X IPA 1 dan X IPA
2 karena belum mencapai KKM untuk mata pelajaran Pendidikan Agama Kristen khususnya pada kemampuan bersikap kritis terhadap nilainilai Kristiani.

\section{Teknik Pengumpulan Data}

1. Observasi

Teknik ini digunakan untuk memperoleh data tentang situasi pembelajaran yang terjadi selama melakukan proses pembelajaran. Kegiatan obsevasi ini dilakukan disetiap pertemuan. Pengumpulan data dilakukan dengan instrumen lembar pengamatan.

2. Wawancara

Wawancara dilakukan pada siswa dengan menggunakan pedoman wawancara yang berisi tentang petunjuk garis besar isi wawancara.

3. Tes

Dalam penelitian ini tes digunakan untuk mengumpulkan data tentang hasil belajar siswa dalam upaya peningkatan prestasi siswa.

\section{Teknik Dokumentasi}

Teknik ini digunakan untuk mendapatkan data berupa foto atau gambar yang digunakan untuk menggambarkan secara visual kondisi yang terjadi pada saat proses belajar mengajar berlangsung.

\subsection{Prosedur Penelitian Tindakan Kelas}

Sebelum mengadakan penelitian, peneliti terlebih dahulu mengawali dengan pra-penelitian. Kegiatan ini dilakukan terhadap mata pembelajaran Agama Kristen dan budi pekertisebelum menggunakan metode concept sentence. Kegiatan yang dilakukan yaitu mengadakan observasi terhadap situasi awal di dalam kelas yang mencakup observasi kegiatan guru, observasi kelas dan observasi terhadap siswa. Setelah mengadakan kegiatan pra-penelitian, peneliti mengadakan penelitian di dalam kelas dengan menggunakan metode concept sentence.

Penelitian ini dilakukan dalam bentuk siklus, masing-masing siklus terdiri dari perencanaan, tindakan, pengamatan dan refleksi. Penelitian ini didesain sebagai Penelitian Tindakan Kelas (PTK) yang akan dilakukan dengan beberapa siklus. Adapun langkah-langkah setiap siklus adalah sebagai berikut: 


\section{Perencanaan}

Pada siklus pertama diawali dengan membuat perencanaan tentang materi dan pelaksanaan tindakan berupa penyiapan pembelajaran menggunakan metode consept sentenceyang akan dilakukan di kelas. Perencanaan ini disusun oleh peneliti. Kemudian menyusun rencana pembelajaran. Langkah-langkah yang dilakukan dalam perencanaan tindakan antara lain sebagai berikut :

a. membuat RPP dengan materi yang diajarkan,

b. menyiapkan metode concept sentence

c. menyusun lembar kerja siswa,

d. menyiapkan instrumen yang

diperlukan dalam pembelajaran yang akan dilakukan,

e. menyusun soal evaluasi.

\section{Tindakan}

Tindakan pada mata pelajaran Agama Kristen dan Budi Pekerti menggunakan metode concept sentence, langkah yang dilakukan pada waktu tindakan adalah membawa kesiapan siswa untuk masuk ke materi dengan menyesuaikan keadaan siswa pada pembelajaran yang akan disampaikan.

\section{Monitoring Tindakan}

Pada saat proses pembelajaran berlangsung, observer mengamati segala yang dilakukan oleh siswa. Pengamatan tersebut meliputi aktivitas siswa dan guru, keaktifan siswa, kreativitas yang dilakukan oleh guru melalui penggunaan metode concept sentencedan interaksi siswa dengan guru, siswa dengan siswa dan bahan ajar, pembelajaran yang membuat siswa merasa senang dan cara guru membimbing siswa dalam pembelajaran. Pada kegiatan pengamatan ini, peneliti menggunakan instrumen observasi antara lain lembar observasi.

\section{Refleksi}

Dalam tahap ini, peneliti bersama kolaborator (guru standar kompetensi kemampuan bersikap kritis terhadap nilai- nilai Kristiani) melakukan analisis dan memaknai hasil tindakan siklus 1 . Apabila dalam hasil refleksi terdapat aspek-aspek yang belum dicapai/berhasil, maka akan dilakukan perbaikan pada siklus II. Pelaksanaan siklus II akan dilaksanakan setelah refleksi pada siklus I. Apabila di dalam siklus tersebut belum memenuhi kriteria yang ingin dicapai maka dilakukan siklus selanjutnya untuk memperbaiki kriteria yang sudah ditentukan.

\subsection{Keabsahan Data}

Pada penelitian ini, triangulasi yang digunakan adalah triangulasi sumber dan triangulasi metode:

1. Triangulasi Sumber

Triangulasi sumber adalah mengecek balik derajat kepercayaan yang berbeda. Misalnya membandingkan beberapa sumber data dengan metode yang sama.

2. Triangulasi Metode

Triangulasi metode adalah mengecek derajat kepercayaan data hasil pengamatan dengan data hasil wawancara.

\subsection{Teknik Analisis Data}

\subsubsection{Partisipasi aktif siswa}

Untuk mengetahui apakahmetode concept sentencedapat membuat siswa lebih aktif dalam mengikuti mata pelajaran Agama Kristen dan Budi Pekerti, data yang digunakan terdapat pada lembar observasi yang kemudian dianalisis secara deskriptif. Penilaian dapat dilihat dari hasil skor pada lembar observasi yang digunakan. Data observasi yang telah diperoleh, dihitung, kemudian dipersentasekan. Sehingga dapat diketahui seberapa besar peningkatan partisipasi siswa dalam pembelajaran. Kriteria menghitung persentase partisipasi siswa berdasarkan lembar observasi adalah sebagai berikut :

Tabel 2. Kriteria Aktivitas Individu

\begin{tabular}{|c|c|}
\hline persentase & kriteria aktivitas siswa \\
\hline $81 \%-100 \%$ & sangat tinggi \\
\hline $61 \%-80 \%$ & Tinggi \\
\hline $41 \%-60 \%$ & Sedang \\
\hline $21 \%-40 \%$ & Rendah \\
\hline $0 \%-20 \%$ & sangat rendah \\
\hline
\end{tabular}

(Riduwan, 2009: 15)

Cara menghitung persentase aktivitas siswa berdasarkan lembar observasi untuk tiap pertemuan adalah sebagai berikut : 


\author{
SkorPerolehan \\ Persentase $=\frac{(\text { Jumlahsiswayangberpartisipasi }}{\begin{array}{c}\text { Skormaksimal } \\ \text { (Jumlahsiswakeseluruhan })\end{array}} \times 100 \%$
}

(Martinus, 2017: 49)

Dalam penelitian ini indikator yang dicapai bisa dilihat dari pencapaian poin-poin yang tertera dalam partisipasi belajar siswa. Adapun poin-poin yang diamati untuk mengukur peningkatan partisipasi antara lain:

a. mendengar penjelasan,

b. mencatat penjelasan,

c. memperhatikan pembelajaran,

d. bertanya,

e. menjawab pertanyaan,

f. mengeluarkan pendapat,

g. menghargai pendapat teman,

h. mampu menjelaskan kembali.

\subsubsection{Prestasi Belajar Siswa}

Untuk mengetahui peningkatan prestasi belajar siswa, peneliti menggunakan Kriteria Ketuntasan Minimal (KKM) pada mata pelajaran Agama Kristen dan Budi Pekerti,yaitu75. Bila siswa telah mencapai nilai sama atau lebih besar dari 75 dengan prosedur rentang nilai 10-100, maka dapat dikatakan memenuhi KKM. Tetapi apabila siswa mendapatkan nilai kurang dari 75 dikatakan masih di bawah KKM.

\subsubsection{Kriteria Keberhasilan}

Dari semua siklus yang telah dilakukan maka dapat dikatakan berhasil apabila partisipasi dan prestasi belajar siswa meningkat dan apabila belum memenuhi target maka akan dilanjutkan ke siklus berikutnya. Hal tersebut bisa dilihat dari hasil pengamatan secara langsung dalam proses pembelajaran di kelas dengan berdasarkan kriteria sebagai berikut:

1. Partisipasi aktif siswa dikatakan berhasil jika partisipasi belajar 75\% siswa secara aktif berperan selama proses pembelajaran berlangsung, dengan melihat dari aspekaspek yang diamati dalam lembar observasi selama penelitian berlangsung.

2. Prestasi belajar siswa dikatakan berhasil jika prestasi belajar $75 \%$ siswa pada akhir siklus telah mencapai 75. Hal tersebut sesuai dengan Kriteria Ketuntasan Minimal (KKM) yang telah diterapkan oleh SMA Negeri 3 Kota Soronguntuk mata pelajaran (mapel).

\section{PEMBAHASAN}

\subsection{Pelaksanaan Penelitian Tindakan Kelas Menggunakan Metode Consept Sentence}

Pelaksanaan metode consept sentenceuntuk meningkatkan partisipasi aktif dan prestasi belajar siswa dilakukan dalam dua siklus dan dilaksanakan dalam empat pertemuan di kelas. Penerapan metode consept sentencepada siklus I dilakukan dalam dua kali pertemuan, tetapi di dalam pelaksanaannya belum tercipta peningkatan partisipasi aktif dan prestasi belajar siswa secara maksimal, maka peneliti sepakat untuk melanjutkan pada siklus berikutnya yaitu siklus II. Siklus demi siklus terbentuk untuk memberikan perbaikan dan perbandingan di dalam pembelajaran agar partisipasi aktif dan prestasi belajar lebih meningkat sesuai dengan apa yang diharapkan peneliti.

Dari pernyataan tersebut dapat disimpulkan bahwa mata pelajaran Agama Kristen dan budipekerti dengan menggunakan metode consept sentenceini dapat memberi kemudahan bagi siswa dalam memahami materi yang diberikan guru. Dalam pembelajaran siklus I masih ada siswa yang kurang dapat memahami materi pelajaran, permasalahan yang diberikan oleh guru serta belum semua siswa menunjukkan partisipasi aktif selama proses pembelajaran dengan menggunakan metode ini. Akan tetapi setelah siklus II para siswa berangsur-angsur dapat memahami materi, serta hampir semua siswa berpartisipasi aktif selama proses pembelajaran dengan menggunakan metode consept sentence. Untuk menilai kriteria keberhasilan prestasi belajar siswa, peneliti menggunakan kriteria ketuntasan minimal (KKM) yang ditetapkan SMA Negeri 3 Kota Sorong. Dalam mengadakan penilaian peneliti mengukur keberhasilan prestasi siswa menggunakan soal setelah tindakan dilakukan.

\subsection{Pembahasan Partisipasi Aktif Siswa}

Hasil penelitian tindakan siklus I dan II dengan penggunaan metode consept 
sentencemenunjukkan adanya peningkatan terhadap aktivitas belajar siswa. Peningkatan terjadi pada observasi siklus II di mana dalam observasi ini yang diamati adalah partisipasi aktif siswa. Dari hasil observasi diperoleh data aktivitas siswa sebagai berikut:

Tabel 7. Peningkatan Partisipasi Aktif Siklus I dan Siklus II

\begin{tabular}{||l|l|l|l||}
\hline \hline aspelk yang diamati & siklus I & siklus II & $\begin{array}{l}\text { peningkatan } \\
\text { partisinasi }\end{array}$ \\
\hline mendengarkan penielasan & $54 \%$ & $71 \%$ & $17 \%$ \\
\hline mencatat penielasan & $43 \%$ & $69 \%$ & $26 \%$ \\
\hline mernperchatikan pembelajaran & $49 \%$ & $60 \%$ & $11 \%$ \\
\hline Bertanya & $43 \%$ & $66 \%$ & $23 \%$ \\
\hline meniawab pertanxaan & $49 \%$ & $66 \%$ & $17 \%$ \\
\hline mengeluarkan pendapat & $46 \%$ & $63 \%$ & $17 \%$ \\
\hline menghargai pendapat teman & $49 \%$ & $66 \%$ & $17 \%$ \\
\hline mampu menielaskan kembali & $40 \%$ & $60 \%$ & $20 \%$ \\
\hline Jumlah & $\mathbf{3 7 1} \%$ & $\mathbf{5 2 0} \%$ & $\mathbf{1 4 9} \%$ \\
\hline rata-rata & $\mathbf{4 6} \%$ & $\mathbf{6 5} \%$ & $\mathbf{1 9} \%$ \\
\hline
\end{tabular}

Berdasarkan hasil observasi yang dapat dilihat dari tabel di atas dapat dilihat adanya peningkatan frekuensi dari siklus I sampai ke siklus II. Setiap indikator masing-masing siklus juga mengalami peningkatan. Pada siklus I dan siklus II peningkatan partisipasi siswa yang paling tinggi adalah mencatat penjelasan, karena terjadi peningkatan sebesar $26 \%$ dan peningkatan partisipasi aktif siswa yang paling rendah adalah indikator bertanya, karena hanya terjadi peningkatan sebesar $11 \%$.

Jadi dapat disimpulkan bahwa dengan penggunaan metode consept sentencedalam mata pelajaran Agama Kristen dan budi pekerti dapat meningkatkan partisipasi aktif siswa dalam proses pembelajaran. Untuk membuktikannya dapat dilihat dalam diagram berikut:

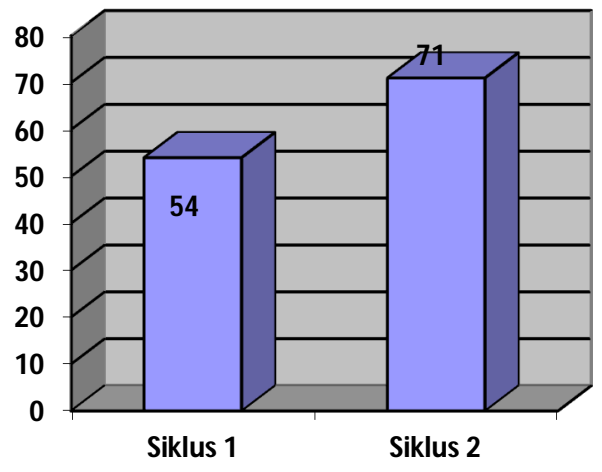

\section{Gambar 3. Diagram Persentase Mendengarkan Penjelasan}

Pada indikator mendengarkan penjelasan persentase siswa dalam kelas pada siklus I sebesar $54 \%$ dan pada siklus II sebesar $71 \%$. Pada diagram di atas menunjukkan bahwa partisipasi aktif siswa untuk mendengarkan penjelasan guru dari siklus I ke siklus II persentasenya meningkat.

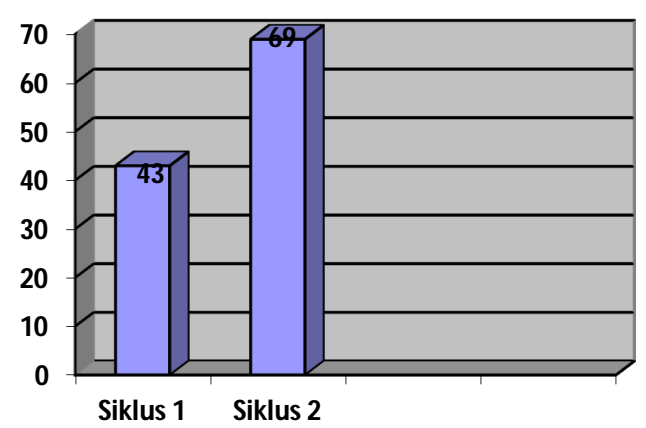

\section{Gambar 4. Diagram Persentase Mencatat Penjelasan}

Pada indikator mencatat penjelasan persentase siswa dalam kelas pada siklus I sebesar 43\% dan pada siklus II sebesar 69\%. Pada diagram di atas menunjukkan bahwa partisipasi siswa dari siklus I ke siklus II terjadi peningkatan persentase siswa yang sangat signifikan, karena siswa mulai dapat mengerti dan lebih mudah menangkap pembelajaran yang disampaikan menggunakan metode concept sentence, sehingga siswa dapat mencatat inti dari penjelasan guru pada setiap materi yang disampaikan. 


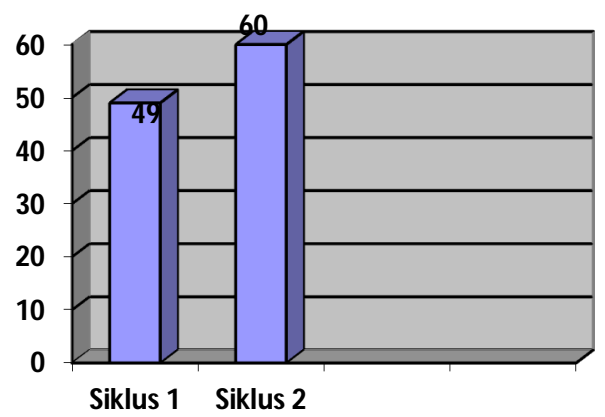

\section{Gambar 5. Diagram persentase Memperhatikan Pembelajaran}

Pada indikator memperhatikan pembelajaran persentase siswa dalam kelas pada siklus I sebesar $49 \%$ dan pada siklus II sebesar $60 \%$. Pada diagram di atas menunjukkan bahwa terjadi peningkatan partisipasi aktif siswa untuk memperhatikan penjelasan guru dari siklus I ke siklus II, karena siswa menjadi tertarik dengan menggunakan metode consept sentence.

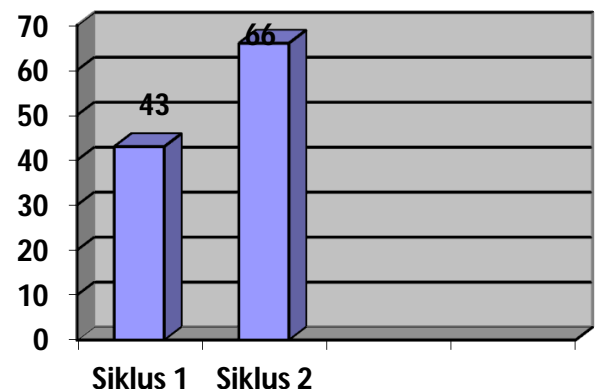

\section{Gambar 6. Diagram persentase Bertanya}

Pada indikator bertanya persentasae siswa dalam kelas pada siklus I 43\% dan pada siklus II sebesar $66 \%$. Pada diagram di atas menunjukkan bahwa partisipasi aktif siswa untuk mendengarkan penjelasan guru dari siklus I ke siklus II juga mengalami peningkatan meskipun dalam persentase yang kecil. Hal ini terjadi karena adanya keengganan dan ketakutan siswa dalam bertanya, tetapi dengan adanya perubahan media yang digunakan guru dalam mengajar sedikit banyak mengubah siswa untuk lebih aktif dalam bertanya.

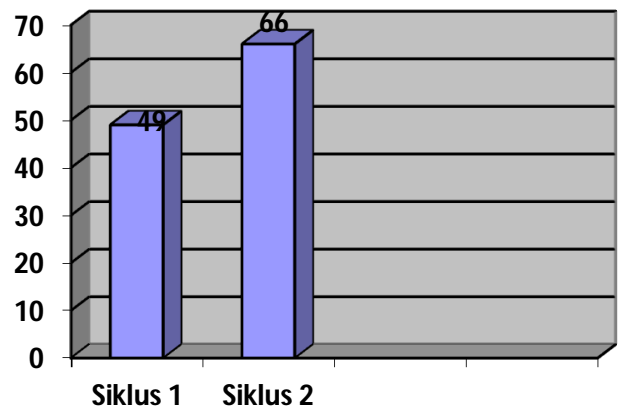

Gambar 7. Diagram Persentase Menjawab Pertanyaan

Pada indikator menjawab pertanyaan persentase siswa dalam kelas pada siklus 1 sebesar $49 \%$ dan pada siklus II sebesar $66 \%$. Pada diagram di atas menunjukkan bahwa partisipasi aktif siswa untuk menjawab pertanyaan dari siklus I ke siklus II persentasenya meningkat.

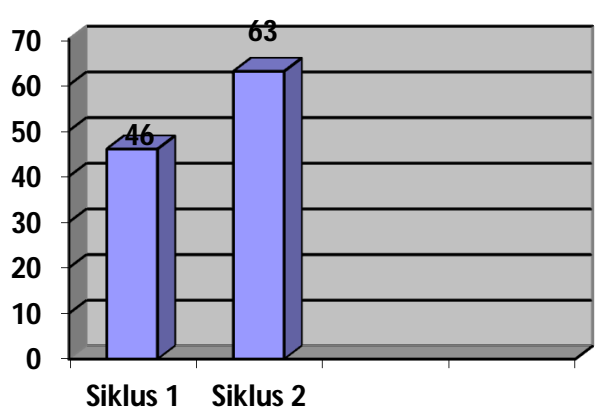

\section{Gambar 8. Diagram Persentase Mengeluarkan Pendapat}

Pada Indikator mengeluarkan pendapat persentase siswa dalam kelas pada siklus I sebesar $46 \%$ dan pada siklus II sebesar $63 \%$. Pada diagram di atas menunjukkan bahwa partisipasi aktif siswa untuk mengeluarkan pendapat dari siklus I ke siklus II persentasenya meningkat meskipun belum semua siswa dapat melakukannya. 


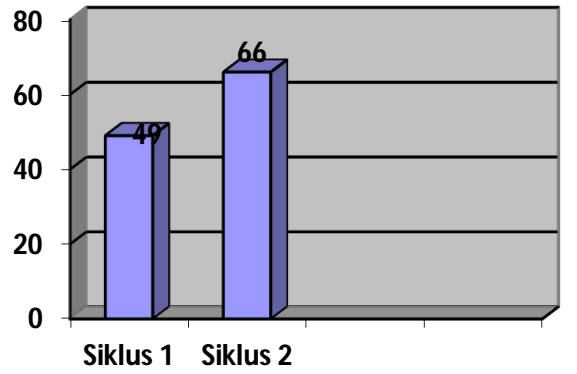

\section{Gambar 9. Diagram Persentase Menghargai Pendapat Teman}

Pada indikator menghargai pendapat teman persentase siswa dalam kelas pada siklus I sebesar 49\% dan pada siklus II sebesar 66\%. Pada diagram di atas menunjukkan bahwa partisipasi aktif siswa untuk menghargai pendapat teman dari siklus I ke siklus II persentasenya meningkat.

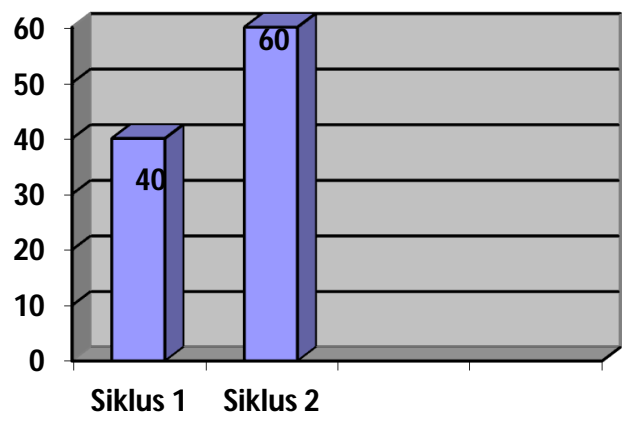

\section{Gambar 10. Diagram Persentase Mampu Menjelaskan Kembali}

Pada indikator refleksi/mampu menjelaskan kembali persentase siswa dalam kelas pada siklus I sebesar $40 \%$ dan pada siklus II sebesar $60 \%$. Pada diagram di atas menunjukkan bahwa partisipasi aktif siswa untuk refleksi/menjelaskan kembali dari siklus I ke siklus II persentasenya meningkat.

\subsection{Pembahasan Prestasi Belajar Siswa}

Penilaian yang digunakan pada setiap siklus adalah dengan menggunakan tes dan dilaksanakan pada setiap akhir siklus dengan soal-soal yang sesuai dengan materi yang diberikan kepada siswa. Hal ini dilakukan untuk mengukur sejauh mana siswa dapat menguasai materi yang telah disampaikan menggunakan metode consept sentence. Hasil penelitian tindakan siklus I dan II dengan penggunaan metode consept sentencemenunjukkan adanya peningkatan terhadap prestasi belajar siswa.

Dari pernyataan tersebut, dapat disimpulkan bahwa dengan menggunakan metode consept sentencedapat menaikkan ingatan yang berarti dapat meningkatkan pestasi belajar siswa. Peningkatan prestasi belajar siswa dapat dilihat pada tabel berikut:

Setelah dilakukan penelitian yang dimulai dari tahapan siklus I, sampai pada tahapan siklus II dapat dilihat adanya peningkatan partisipasi aktif dan prestasi belajar siswa dengan menggunakan metode consept sentence. Berdasarkan pemaparan prestasi belajar di atas dapat diberikan penjelasan bahwa telah terjadi peningkatan prestasi belajar siswa dari siklus I mencapai rata-rata 69,64\% naik menjadi rata-rata $78,4 \%$ pada tahap siklus II. Dari rata-rata tersebut dapat diketahui peningkatan rata-rata $8,76 \%$ dari siklus I ke siklus II. Dapat disimpulkan bahwa dengan penggunaan metode consept sentencepadamata pelajaran Agama Kristen dan Budi pekerti dapat meningkatkan prestasi belajar siswa.

Peningkatan prestasi belajar dapat dilihat pada diagram sebagai berikut:

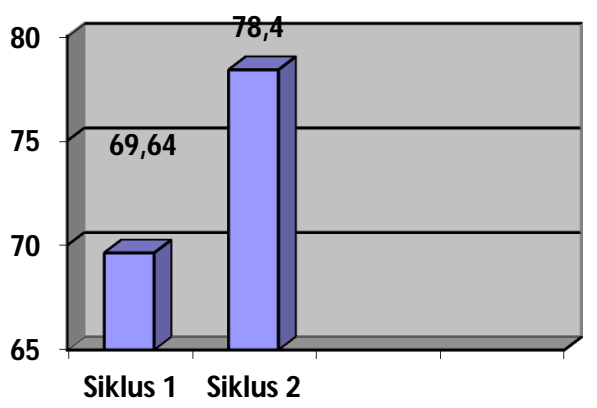

\section{Gambar 11. Diagram Nilai Rata-Rata Kelas}

Pada diagram di atas menunjukkan bahwa terdapat peningkatan rata-rata nilai hasil belajar dari siklus I sebesar 69,64 sedangkan pada siklus II meningkat menjadi sebesar 78,4 


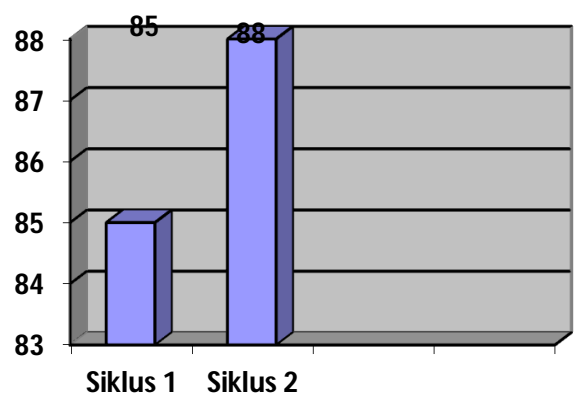

Gambar 12. Diagram Nilai Tertinggi Siswa

Pada diagram di atas menunjukkan bahwa terdapat peningkatan nilai tertinggi yang diperoleh siswa dari siklus I sebesar 85 sedangkan pada siklus II meningkat menjadi sebesar 88

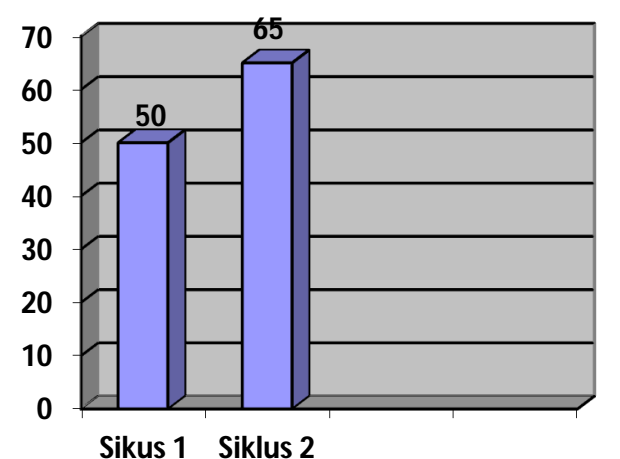

\section{Gambar 13. Diagram Nilai Terendah Siswa}

Pada diagram di atas menunjukkan bahwa terdapat peningkatan nilai terendah yang diperoleh siswa dari siklus I sebesar 50 sedangkan pada siklus II meningkat menjadi sebesar 65 .

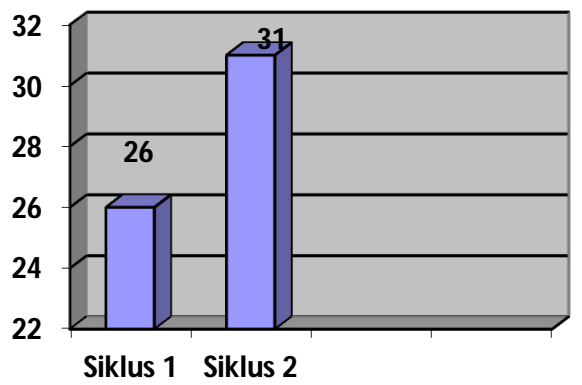

\section{Gambar 14. Diagram Jumlah Tuntas Individu}

Pada diagram di atas menunjukkan bahwa terdapat peningkatan jumlah tuntas individu atau siswa yang mencapai Kriteria Ketuntasan Minimal (KKM) dari siklus I sebesar 26 siswa sedangkan pada siklus II meningkat menjadi sebesar 31 siswa.

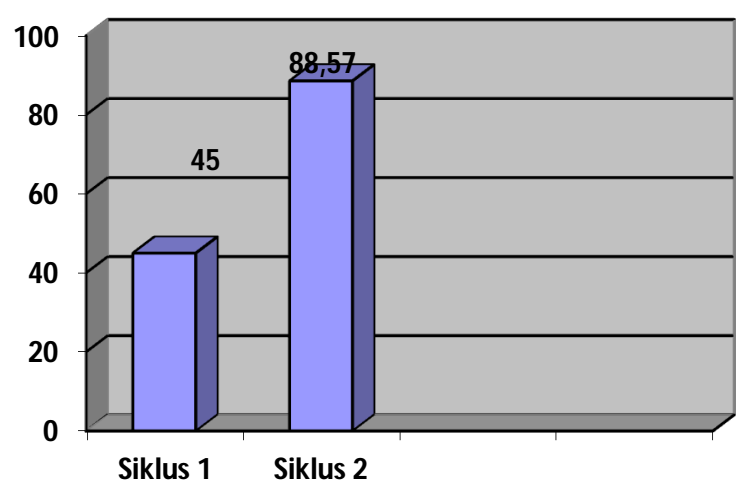

\section{Gambar 15. Diagram Persentase Ketuntasan Individu}

Pada diagram di atas menunjukkan bahwa terdapat peningkatan persentase ketuntasan individu. Siklus I terdapat $45 \%$ siswa yang telah mencapai ketuntasan atau mencapai Kriteria Ketuntasan Minimal (KKM). Sedangkan pada siklus II terdapat $88,57 \%$ siswa telah mencapai KKM.

\section{PENUTUP}

\subsection{Kesimpulan}

Berdasarkan hasil analisis data dan pembahasan yang telah peneliti lakukan, aktivitas belajar siswa kelas X IPA 1 dan X IPA 2 di SMA Negeri 3 Kota Sorong untuk mata pelajaran Agama Kristen dan budi pekerti, dapat ditarik kesimpulan sebagai berikut:

1. Penerapan pembelajaran dengan menggunakan metode consept sentencedapatmeningkatkan kemampuan bersikap kritis terhadap nilai- nilai Kristiani padamata pelajaran Agama Kristen dan budi pekerti siswa kelas X IPA 1 dan X IPA 2 dilihat dari adanya peningkatan persentase,

2. Peningkatannya dapat dilihat dari hasil observasi pada siklus I dan siklus II. Pada Aspek mendengarkan penjelasan siklus I sebesar $54 \%$ dan siklus II sebesar $71 \%$. Aspek mencatat penjelasan siklus 1 sebesar $43 \%$ dan siklus II sebesar 69\%. Aspek memperhatikan pembelajaran siklus I sebesar 49 dan siklus II sebesar $60 \%$. Aspek bertanya siklus I sebesar $43 \%$ dan pada siklus II sebesar 66\%. Aspek 
menjawab pertanyaan siklus I sebesar $49 \%$ dan siklus II sebesar 66\%. Aspek mengeluarkan pendapat siklus I sebesar $46 \%$ dan pada siklus II sebesar 63\%. Aspek menghargai pendapat teman siklus I sebesar 49\% dan pada siklus II sebesar 66\%. Aspek mampu menjelaskan kembali siklus I sebesar $40 \%$ dan pada siklus II sebesar 60\%. Hal ini menunjukkan bahwa terjadi peningkatan terhadap partisipasi aktif siswa pada Standar Kompetensi kemampuan bersikap kritis terhadap nilai- nilai Kristiani.

3. metode consept sentencejuga dapat meningkatkan hasil belajar pada mata pelajaran Agama Kristen dan budi pekertidi kelas. Peningkatan hasil belajar ini dapat dilihat dari adanya perubahan nilai rata-rata yang diperoleh siswa pada setiap akhir siklus. Nilai rata-rata yang diperoleh siswa pada siklus I sebesar 69,64 dan siklus II sebesar $78,4 \mathrm{Hal}$ tersebut membuktikan bahwa dengan menggunakan metode consept sentencedapat meningkatkan prestasi belajar siswa.

\subsection{Saran}

Berdasarkan hasil penelitian dan pembahasan maupun kesimpulan di atas, dapat diajukan beberapa saran:

1. Guru perlu mengupayakan partisipasi belajar siswa dengan cara melanjutkan pembuatan metode consept sentencepada mata pelajaran Agama Kristen dan Budi Pekerti untuk pertemuan-pertemuan selanjutnya agar siswa tertarik dalam memahami materi yang diberikan dalam proses pembelajaran sehingga partisipasi siswa dapat bertahan bahkan meningkat.

2. Guru perlu mengupayakan prestasi belajar siswa dengan cara melanjutkan pembuatan metode consept sentencepada mata pelajaran Agama Kristen dan Budi Pekerti untuk pertemuan-pertemuan selanjutnya agar siswa tertarik dalam memahami materi yang diberikan dalam proses pembelajaran sehingga prestasi siswa dapat bertahan bahkan meningkat.

\section{DAFTAR PUSTAKA}

[1] Mulyasa. (2004). Menjadi Guru professional. Bandung: PT Remaja Rosdakarya.

[2] Nana Sudjana. (2006). Penilaian Hasil Proses Belajar Mengajar. Bandung: PT Remaja Rosdakarya.

[3] Riduwan. (2009). Skala Pengukuran Variabel-Variabel Penelitian. Bandung: Alfabeta.

[4] Rochiati Wiriaatmadja. (2009). Metode Penelitian Tindakan Kelas. Bandung: PT Remaja Rosdakarya.

[5] Slameto. (2010). Belajar dan FaktorFaktor yang Mempengaruhi. Jakarta: Rineka Cipta.

[6] Sugihartono. (2007). Psikologi Pendidikan. Yogyakarta: UNY Press.

[7] Suharsimi Arikunto. (2009). Dasar-dasar Evaluasi Pendidikan (Edisi Revisi, cetakan 7). Jakarta: Bumi Aksara

[8] Suharsimi Arikunto, dkk. (2017). Penelitian Tindakan Kelas.Jakarta : Bumi Aksara.

[9] Sumadi Suryabrata. (2006). Psikologi Pendidikan. Jakarta: PTRaja Grafindo Persada.

[10] Suryobroto. (1997). Proses Belajar Mengajar di Sekolah. Jakarta: PT Rineka Cipta.

[11] Susilo. (2007). Panduan Penelitian Tindakan Kelas. Yogyakarta: Pustaka Book Publlisher.

[12] Suyitno Imam (2017) Karya Tulis Ilmiah (cetakan ketiga) .Bandung: PT Refika Aditama.

[13] Suyitno Imam (2017) Penulisan Makalah Ilmiah (cetakan ketiga). Bandung: PT Refika Aditama

[14] Suyitno Imam (2017) Penulisan Artikel Ilmiah (cetakan ketiga). Bandung: PT Refika Aditama

[15] Bessie Yethie (2015) Hidup Bagi KristusPendidikan Agama Kristen Dan Budi Pekerti (Buku Pelajaran PAK) Jakarta : BPK Gunung Mulia 